\title{
INNOVATION EDUCATION IN THE WRITING OF SCIENTIFIC PAPERS
}

\section{Deti Rostini, Ade Tutty Rokhayati Rosa}

Universitas Islam Nusantara

yankty59@gmail.com

\section{Article History}

accepted 30/09/2018

approved $12 / 10 / 2018$

published 30/10/2018

\section{Keywords}

Scientific work, Strength, Development, Value function,

Professional model.

\begin{abstract}
Among the Development of teachers professionalism is in the ability to make scientific papers which is believed to improve professionalism and improve the quality of learning ,.Among the problems of elementary schools teachers in the focus areas is lack of understanding in the writing of scientific papers. Whereas professional teachers should be able to write scientipic papers. Among the causes are long willingness, ability, coaching. This study aims to provide news strategies /theories and improvements in the willingness and ability of teachers to write scientifics papers.mastery of methodology ,research design , practical ways, and tips for successful writing of scientific papers .Problem solving frameworks by holding a workshop. The methode Is qualitative analytic,descriptive designed through $R \& D$. This reseach belongs to appropriate technology development of empowerment model and professionalism of teachers of elementary school in West Java.
\end{abstract}

Social, Humanities, and Education Studies (SHEs): Conference Series https://jurnal.uns.ac.id/shes

p-ISSN 2620-9284 e-ISSN 2620-9292 


\section{PENDAHULUAN}

Pengembangan profesi guru salah satunya adalah pengembangan kemampuan guru dalam membuat karya tulis ilmiah..Untuk menjamin keberhasilan proses pemberdayaan guru, dapat digunakan model pemberdayaan Khan (dalam Wahibur Rokhman, 2003) dengan paradigma-paradigma desire, trust, confident, credibility, accountability, communication.

Berdasarkan latar belakang diatas dapat diidentifikasi masalahnya diantaranya diawali dari hasil penelusuran sementara di berbagai media cetak, media elektronik maupun melalui media IT; survai ke beberapa sekolah (SDN/ MI yang dijadikan Fokus penelitian yang ada di Kabupaten Bandung, pengamatan langsung, hasil wawancara dengan berbagai elemen terkait, para pakar dan hasil beberapa penelitian yang lain di era digital ini khususnya pada guru-guru sekolah dasar saat mengajar, sementara dalam permasalahan ini diantaranya dapat diidentifikasi data sebagai berikut :

a. Banyak guru khususnya guru SD/ MI yang macet kenaikan pangkatnya khususnya dari mulai III b sampai IV/a ke IV/b dan seterusnya terkendala hanya karena mereka tidak dapat menulis karya ilmiah yang baik dan benar. Permasalahan tersebut disebabkan oleh berbagai faktor, diantaranya yang sangat penting adalah kemauan dan kemampuan menulis guru dalam penulisan/ pembuatan karya ilmiah yang masih rendah

b. Bagi sebagian guru SD/ MI ,bahwa karya ilmiah merupakan hal yang dianggap "pekerjaan yang sulit".Akibatnya karya ilmiah menjadi hambatan dalam berbagai hal. Padahal kemampuan menulis karya ilmiah menjadi keharusan bagi seorang guru profesional.

c. Sebagian guru-guru Sekolah Dasar/MI di daerah Kabupaten Bandung Propinsi belum banyak mengetahui dan memahami sistem kenaikan pangkat yang harus melalui penulisan karya ilmiah bahwa menulis karya ilmiah merupakan syarat mutlak bagi guru yang akan naik pangkat/ golongan tertentu.

d. Banyak guru yang tidak menyadari bahwa menulis / membuat suatu karya ilmiah dan mengambangkannya merupakan suatu kebutuhan yang sangat krusial bagi seorang guru dalam menjalankan tugasnya, kebutuhan kehidupanya baik jangka pendek maupun jangka panjang.

Menurut Amat Jaedum (2011), Fakta di lapangan menunjukkan betapa masih langkanya Guru yang mau, mampu, dan biasa melakukan kegiatan penulisan karya ilmiah. Dari ribuan Guru yang ada, hanya puluhan saja yang telah menunjukkan kemampuan, kemauan, dan kebiasaan menulis ini. Ini ditandai dari kemampuan mereka mencapai golongan IVb dan kemunculan beberapa tulisan pada majalah atau terbitan lainnya.

"Menurut Anang Santoso (2010) bahwa : "dalam peraturan kenaikan pangkat terbaru seorang guru bergolongan III/a yang akan naik pangkat ke III/b harus menulis karya ilmiah.Banyak guru khususnya guru SD yang macet kenaikan pangkatnya dari IV/a ke IV/b hanya karena mereka tidak dapat menulis karya ilmiah. Mereka selalu mengeluh "saya tidak dapat menulis karya ilmiah", "saya bingung menulis karya ilmiah", "apa yang dapat saya tulis", dan sebagainya. Apa yang dituntut kepada kita sebagai guru bukan hal yang baru. Menulis karya ilmiah adalah sebuah keharusan, sebuah kemestian, sebuah keniscayaan"

Hal tersebut juga dapat diperlihatkan pada hasil penelitian sebagai berikut : (sumber Titi larasati) 
Diagram 3. Prosentase Faktor-Faktor Penghambat Penulisan KTI

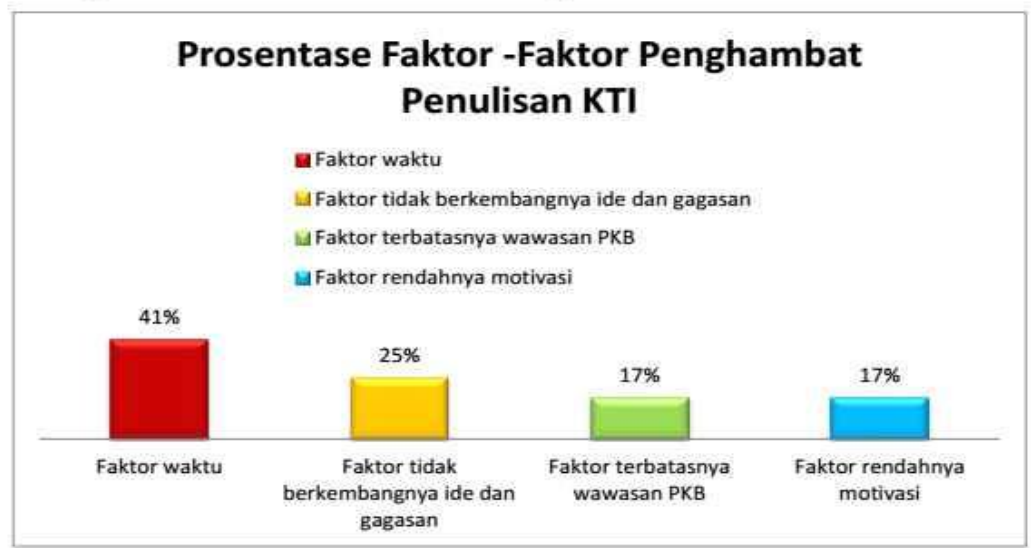

Kegiatan pengembangan profesi, dalam hal ini menulis karya tulis ilmiah hendaknya dipandang sebagai bagian integral tugas, kewajiban, dan tangungjawab setiap guru.

\section{METODE}

Tehnik dan metode dalam penelitian ini adalah menggunakan metode Deskriptif analitik kualitatif karena penelitian ini selain mendeskripsikan juga dirancang untuk melakukan analisis dan estimasi tentang apa yang harus dilakukan untuk mencapai keadaan yang akan datang.

1. Rancangan Penelitian. Penelitian ini dirancang melalui Research and Development, oleh karena ini setiap langkan disesuaikan dengan kaidah yang ada. Sebagai gambaran melalui studi literature dan studi lapangan,

2. Metode pembelajaran, yang digunakan untuk mendukung keberhasilan program penelitian ini antara lain sebagai berikut: (1) Ceramah dan Tanya Jawab yang dilakukan oleh Pakar pendidikan beserta Tim Peneliti. Metode ini dipilih untuk menjelaskan tentang materi yang bersifat teoritik terkait dengan aturan perundangan yang menyangkaut kenaikan pangkat.

3. Metode yang digunakan dalam pembinaan bimbingan dan pelatihan, pendampingan dalam tekhnik penulisan karya ilmiah ini diantaranya adalah: (1) Peningkatan Proses dan hasil menulis melalui Metode Penyuntingan ;(2) Peningkatan kemampuan membedakan Fakta dan Opini dalam melalui Metode Inkuiri ;(3) Peningkatan kompetensi guru dalam bidang pedagogik dan profesional; (4) Peningkatan kemampuan guru dalam menyusun hasil karya tulis ilmiah; (5) Membangkitkan kinerja guru dalam pemanfaatan hasil-hasil kerja yang terdokumentasi;(6) Peningkatkan profesionalisme guru SD/MI dalam kegiatan profesi kompetensi guru;(7) Peningkatan Keterampilan Menulis dengan Metode Copy By Master ;(5) Peningkatan Kemampuan Membaca Cepat dengan Metode Pelatihan Berulang ; (6)) Peningkatan Kemampuan Mengapresiasi hasil penulisan peserta workshopMetode atau pendekatan yang akan dilakukan melalui pendekatan desktiptif partisipasif penemuan, pengembangan pendidikan ; (2) Jenis kegiatan yang dilakukan adalah bimbingan dan pelatihan berupa penyuluhan, ceramah, diskusi dan praktik dan workshop mengenai berbagai jenis penulisan karya ilmiah diantaranya dalam bentuk makalah, diktat/buku ajar, PTK, pelaporan penelitian dan lainnya. Bentuk Layanan : (1) Penyusunan Pedoman Karya IImiah ; (2) Pelatihan Penulisan Karya Ilmiah;(3) Jasa Konsultasi Penulisan pendampingan pembuatan Karya ilmiah. 
HASIL DAN PEMBAHASAN

Pembinaan, pendampingan dan Pelatihan yang diangkat dalam kegiatan penelitian ini adalah kemauan dan kemampuan menulis karya ilmiah bagi guru SD/ MI khususnya pada daerah yang dijadikan focus penelitian .Oleh karena itu, diusulkan kerangka pemecahan masalah secara operasional sebagai berikut:

1. Sebelum proses pembelajaran, dilaksanakan prites guna mengetahui kemampuan awal peserta pada saat mengikuti workshop. Skenario pembelajaran dengan menggunakan sistem in class on the job training (praktik di instansi/ lembaga yang dijadikan tempat workshop ) dan presentasi hasil on the job di akhir pembelajaran

2. Memotivasi guru menulis karya tulis ilmiah yang berupa makalah, jurnal, diktat, buku, PTK ,laporan penelitian dan lainnya.

3. Penyelenggaraan pelatihan intensif tentang: .potensi dan peluang guru menulis karya tulis ilmiah berjenis makalah, diktat, laporan penelitian. Penulisan jenis karya tulis ilmiah tersebut, mencakup: (1).Teknik mengidentifikasi, memilih, dan merumuskan topik/judul karya tulis ilmiah; (2).Teknik menyusun kerangka tulisan karya ilmiah; (3).Teknik mengumpulkan bahan-bahan tulisan, mengorganisasikan, dan mengonsep karya tulis ilmiah, dan (4). Teknik menulis dan menyunting karya ilmiah, tekhnik croschek plagiasi dan aplikasinya pada publikasi ilmiah;

Pelatihan dalam teknik penulisan karya ilmiah untuk guru-guru SD/ MI khususnya di lingkungan Kecamatan yang dijadikan focus penelitian di Kabupaten Bandung adalah: Perlombaan peserta workshop sebagai Peningkatan Kegiatan Pengembangan Ilmu ,Tekhnologi ,Seni dan Keterampilan bagi Guru-guru Sekolah Dasar (SD/MI) khususnya dalam efektivitas dan kualitas guru. Diberikan Piagam penghargaan. Workshop dengan pembicara para pakar pendidikan dan penulisan karya ilmiah dengan thema:"Bimbingan dan Pelatihan dalam Tekhnik Penulisan Karya IImiah.Untuk Peningkatan Profesional Guru-Guru SD/ MI Kab.Bandung. Peserta diberikan Sertifikat. Sebagai pengembangan pengetahuan dan aplikasi fungsi nilai pendidikan terhadap pengembangan potensi dan profesional guru, diadakan pembinaan, pelatihan, pendampingan pembuatan/penulisan draft karya ilmiah dan tekhnik publikasi ilmiah. Guru mampu Membuat strategi dalam bentuk makalah system dan tekhnik penulisan karya ilmiah dalam meningkatkan Kompotensi ,profesional guru-guru SD/MI khususnya di daerah/ Kabupaten Bandung yang dijadikan focus penelitian . Hal ini secara umum termasuk dalam Teknologi Tepat Guna berupa Model Pemberdayaan peningkatan professional guru-guru Sekolah dasar /MI . Hasil dari Pelatihan Penulisan Karya Tulis IImiah bagi Guru guru SD/MI yang ada di lingkungan PGRI Kabupaten Bandung antara lain (1) Peserta Pelatihan terdiri dari 42 orang guru SD/ MI ; (2) Materi yang disajikan adalah tentang Menulis (A Challenging Adventure) dan Menuangkan gagasan menjadi Karya Tulis (Artikel), Materi yang diberikan adalah penjelasan tentang motivasi untuk menulis karya ilmiah, etika penulisan ilmiah, teknik penulisan karya ilmiah, kebahasaan dalam ragam karya ilmiah,dan teknik swasunting, peserta pelatihan terlihat tertarik dengan materi yang disajikan dengan serius tapi santai. (3). Pelatihan berlangsung dengan lancar dimana pada tahap awal adalah memotivasi para guru untuk mau menulis dari hal yang sederhana dan menulis tentang apa yang terjadi di sekitar mereka, khususnya menulis tentang peristiwa pembelajaran yang mereka alami dan hadapi. Supaya pelaksanaan pelatihan tidak kaku dan tegang maka penyajian materi dibarengi dengan tanya jawab. (4). Pada saat pelatihan peserta begitu antusias mengikuti pelatihan karena pada sesi tanya jawab panitia menyediakan door prize bagi peserta yang menjawab dengan benar. Berdasarkan pengamatan pada saat pelatihan tidak ditemukan kendala yang signifikan, namun diharapkan adanya proses berkelanjutan untuk meningkatkan keterampilan dalam menulis karya tulis ilmiah bagi guru-guru, karena kita tidak dapat mengingkari bahwa Karya tulis 
ilmiah masih sangat minim yang disebabkan karena ketidaktahuan etika dan teknik penulisannya. Kegiatan Pelatihan Penulisan Karya IImiah dilakukan dengan diskusi pada tiap materi yang disampaikan,peserta dapat berdialog danberdiskusi dengan tim peneliti dan mereka mampu beberapa guru telah dapat menyelesaikannya dengan cukup baik, begitu juga dalam praktek menulis Peserta diminta untuk melakukan praktek/latihan menulis. Peserta dikelompokkan berdasarkan kemampuan menulis yang telahdimiikinya. Tingkat kesulitan dari praktek ini para guru SD/ MI peserta pelatihan disesuaikan dengan kemampuan masing-masing perserta. Pada bagian akhir peserta akan diberi tugas untuk membuat karya tulis berdasarkan bidang keahlian masingmasing. Karya tulis ini merupakan syarat untuk memperoleh sertifikat peserta. Pada penyusunan karya ilmiah ini dilakukan pendampingan oleh fasilitator.

\section{SIMPULAN}

Dari kegiatan Pelatihan yang dilakukan dan dari diskusi serta Tanya jawab dengan guru guru SD/MI yang menjadi subyek penelitian di Lingkungan PGRI Kabupaten dan mengikuti kegiatan Pelatihan dan Bimbingan berupa kegiatan Workshop tersebut dapat diambil disimpulkan penyebab minimnya karya tulis ilmiah yang ditulis oleh guru khususnya guru SD. MI yaitu : (1) Jam mengajar yang padat; (2) Jumlah siswa dalam satu kelas yang tidak sedikit dan tuntutan kurikulum 2013 dimana setiap guru harus menilai per siswa dari segi Afektif, Kognitif dan Psikomotor ; (3) Ketidaktahuan guru tentang etika dan teknik penulisan karya tulis ilmiah; (4) Guru-guru tidak terbiasa dan terlatih untuk mengungkapkan ideidenya dalam bentuk tulisan

\section{DAFTAR PUSTAKA}

Bahdin, Nur Tanjung dan Ardial. (2005).Pedoman Penulisan Karya IImiah(Proposal, Skripsi, dan Tesis) Dan Mempersiapkan Diri Menjadi Penulis Artikel.Jakarta: Prenada Media

Brotowidjoyo, Mukayat D.(1985). Penulisan Karangan IImiah.Jakarta: Akademika Presindo.Depdiknas

Dalam Kegiatan Pelatihan Penulisan Bahan Kuliah (Buku Pegangan Kuliah). Jurusan AP FIP UNY, 16-20 Mei 2003.

Darmastuti Suetrisno. Ir., M.Ed., Peningkatan Mutu Pendidikan Di Sekolah Dasar : Pendekatan

Dirjen Dikdasmen Direktorat Tnaga Kependidikan.(2001). Pedoman Penyusunan KaryaTulis

Dirjen Pendidikan Dasar dan Menengah ,Direktorat TK \& SD Jakarta 2001Haryanto. (2006). Rambu-rambu dan Kiat Menulis Artikel Ilmiah dalam Upaya Penerbitan Berkala

Ilmiah di Bidang Pendidikan dan Angka Kredit Pengembangan Profesi Guru.Jakarta:2001

IImiah Terakreditasi. Disampaikan dalam Lokakarya Penerbitan Majalah IImiah di Jurusan Administrasi Pendidikan Fakultas IImu Pendidikan UNY

Jurnal Penelitian Humaniora di Lembaga Penelitian Universitas Negeri Yogyakarta,Oktober 2003.

Menyeluruh dan Desentralistis tentang Pola dan Strategi Peningkatan Mutu Pendidikan. Depdiknas 
Rosa, atr (2014). Profesi Keguruan \& Profesi Kependidikan , Uninus BandungSoeparno.(2005). Bahasa Indonesia Untuk Penulisan Karya Tulis IImiah. Makalah Disampaikan

Santoso, Anang. 2010. Bahasa Indonesia dalam Karya Ilmiah: Pokok-pokok Pikiran. Makalah disajikan dalam Workshop Peningkatan Kualitas Penelitian Dosen PGSD, FKIP,UNMUL Yoga Guntur Sampurno (yoga_gs@uny.ac.id) Ibnu Siswanto (ibnusiswanto@uny.ac.id)

Suyanto. (2001). Teknik Penulisan Artikel Imiah.Makalah disampaikan dalam Lokarkarya Penulisan

Wibowo. (2001). Managemen Bahasa Pengorganisasian Karangan Pragmatik dalam Bahasa Indonesia untuk Mahasiswa dan Praktisi Bisnis.Jakarta: Gramedia Pustaka Utama

Wijaya Cecep (2014) -"PR"/A-88). Forum Forum Diskusi Wartawan Kabupaten Bandung bidang penulisan opini, artikel, dan karya ilmiah. Kabupaten Bandung, diunduh 10 des 2014 